\title{
Maatschappelijk verantwoord ondernemen en de rol van de overheid
}

\author{
R. Hindriks
}

Ongeveer twee jaar geleden is ook de overheid op verschillende fronten voorzichtig gaan zoeken naar haar rol in het debat over maatschappelijk verantwoord ondernemen. Verschillende ministeries hebben onderzoek laten doen en initiatieven genomen op het gebied zonder zich evenwel een rol toe te eigenen. Bij de begrotingsbehandeling van het ministerie van Economische Zaken voor het jaar 1999 stelde het toenmalige kamerlid Wouter Bos aan de kersverse staatssecretaris van Economische Zaken, de heer Ybema, de vraag welke rol hij voor het departement zag weggelegd op het gebied van maatschappelijk verantwoord ondernemen. De staatssecretaris reageerde als volgt:

"Maatschappelijk verantwoord ondernemen is primair de verantwoordelijkheid van het bedrijfsleven. Die primaire verantwoordelijkheid moeten wij daar ook nadrukkelijk laten. Waar relevant gebeurt zulks vaak in samenspraak met de NGO's, zoals Pax Christi en Amnesty International”.

Hij vervolgt:

"De overheid moet vooral zorgdragen voor transparantie van de markt. Zij moet bevorderen dat er gekomen wordt tot het opstellen van keurmerken. Verder moet zij aandacht blijven vragen voor consumentenbelangen, zogenaamde consumer concerns"!.

De Partij van de Arbeid kan zich in grote lijnen vinden in de opvatting van de staatssecretaris. Het sleutelwoord bij het stimuleren van maatschappelijk verantwoord ondernemen is het bevorderen van transparantie. Bij het algemeen overleg van 23 juni $1999^{2}$ dat volgde op de begrotingsbehandeling bleek echter dat ook de staatssecretaris geen rol voor de overheid zag weggelegd, anders dan voorlichtend en propagerend.

Als reactie op de terughoudende houding van de verschillende departementen zijn Wouter Bos en Mohammed Rabbae in de loop van 1999 op zoek gegaan naar een meer actieve rol voor de overheid. Naar aanleiding van dat onderzoek zijn GroenLinks en de Partij van de Arbeid halverwege vorig jaar begonnen met de ontwikkeling van een initiatief wetsvoorstel op het gebied van maatschappelijke verslaglegging. Rapportage over de maatschappelijke effecten door bedrijven zien we als een uiterst geschikt middel om de transparantie te bevorderen. In dit artikel wordt in algemene termen geschetst welke rol de PvdA en GroenLinks voor maatschappelijke verslaglegging zien en hoe de overheid deze ontwikkelingen kan bevorderen.

Vanaf het begin was voor de twee fracties duidelijk dat maatschappelijk verantwoord ondernemen fundamentele vragen oproept over de rol van de overheid en de grenzen van wet- en regelgeving.

\section{Traditionele rol van de overheid}

In de traditionele opvatting over de rol van de overheid, vraagt zij van het bedrijfsleven niet meer dan datgene wat zij in wetgeving heeft vastgelegd. Buiten de wettelijke grenzen zijn ondernemingen vrij hun activiteiten zo in te richten als zij goed achten.

De heer $D$. Hindriks heeft na het afronden van de Hogere Zeevaartschool te Amsterdam enige tijd als stuurman gewerkt bij Chevron Tankers. Na het behalen van het doctoraal examen economie aan de Universiteit van Amsterdam, heeft de heer Hindriks verschillende financiële functies gehad in het bedrijfsleven. Vanaf 1996 was hij Financieel directeur Thyssen Liften B.V.. Sedert 1 juni 1999 is de heer Hindriks Lid van de Tweede Kamer de Staten-Generaal, waar hij onder meer lid is van de Vaste Commissie voor Economische Zaken en voor Verkeer en Waterstaat. 
Aan de andere kant staan maatschappelijke organisaties die door voorlichting en acties de malatschappij proberen te verbeteren. Zij proberen het bedrijfsleven aan te spreken en hen ervan te overtuigen hun bedrijfsactiviteiten milieu-, dicrof mensvriendelijker te maken.

De overheid is in dic traditionele opvatting geen partij in deze confrontatie tussen ideële organisaties en bedrijven. maar stat boven de partijen. Alleen als een meerderheid van de afgevalardigden in het parlement van mening is dat de grens van het toelaatbare is bereikt, grijpt de overheid in en wel met repressieve wetgeving. zoals in het geval van het verbod op het fokken van nertsen of het importverbod op ivoor.

\section{De moderne overheid}

De bovenstaande opvatting over de rol van de overheid is in mijn ogen wat kaal. Ten eerste is de overheid geen neutrale toezichthouder op de maatschappij. De overheid vertegenwoordigt de bevolking en deelt een groot deel van de in de samenleving levende denkbeelden.

Aan de andere kant keert de bevolking zich steeds meer af van de traditionele politieke partijen. Tegelijkertijd worden steeds meer mensen lid van one-issue-organisaties. Het maatschappelijk debat heeft zich in zekere zin verplaatst van de politicke arena naar de maatschappij zelf. De politiek is steeds minder de autoriteit die van bovenaf normen aan de samenleving oplegt, en steeds meer een deelnemer, die niet pretendeert de waarheid in pacht te hebben. De overheid doet soms een beroep op de bevolking over een onderwerp in discussie te gaan. Een voorbeeld daarvan is de nut-en-noodzaak-discussie. In een nut-en-noodzaak-discussic vraagt de overheid over belangrijke beslissingen de mening van deskundigen en belanghebbenden. Als uit een maatschappelijk debat een consensus is voortgekomen. neemt de overheid bij haar beslissing die lijn zoveel mogelijk over.

Ten derde kan de overheid niet zonder een bepalald morecl besef van haar bevolking. De maatschappij kan niet functioneren als burgers zich slechts aan de bepalingen van de wet houden en voor het overige volstrekt calculerend gedrag vertonen. Het functioneren van de samenleving steunt op het moreel besef van haar burgers. Kinderen galan niet naar school omdat dat verplicht is, maar omdat hun ouders hen motiveren te leren en vooruit te komen in de wereld. De overheid zou er ook niet in slagen iedere dag weer alle onwillige leerplichtige jongeren in de schoolbankjes te krijgen. Niet al het menselijk gedrag is via regels en wetten af te dwingen. Dat is niet wenselijk, maar ook niet nodig. Verreweg het grootste gedeclte van de burgers vertoont uit zichzelf goed gedrag. Daar rekent de overheid bij de uitvoering van haar laken ook nadrukkelijk op. Datzelfde gaat ook in grote lijnen op voor rechtspersonen. Net als van haar burgers verwacht de overheid ook van bedrijven good citizenship.

\section{Tussenconclusic}

In theorie kan de overheid gewenst gedrag afdwingen door wetgeving. In de praktijk ziet zij vaak af van haar bevoegdheid. De overheid geeft er de voorkeur aan dat burgers, maar ook bedrijven zelf tot gedragsaanpassing te komen.

Bekende voorbeelden daarvan zijn de tabaken alcoholindustrie, die zich vrijwillig onthouden van bepaalde reclame-uitingen en die programma's steunen en opzetten ter bestrijding van de schadelijke gevolgen van hun producten. In die situaties speelt de overheid een indirecte rol door bij de branche druk uit te oefenen. De wetenschap dat de overheid tot regelgeving kan overgaan, is vaak al voldoende om bedrijven tot actie aan te zetten.

De PvdA en GroenLinks, gesteund door een meerderheid van de kamer, zien voor een actieve en moderne overheid wel degelijk een rol in het debat rond matschappelijk verantwoord ondernemen.

\section{Regelgering}

Nu de verantwoordelijkheid van de overheid voor de initiaticfinemers vaststond, zagen zij zich voor de taak gesteld regelgeving te ontwikkelen die matschappelijk verantwoord gedrag van ondernemingen kan afdwingen.

Als de overheid iets wil afdwingen dan is de meest voor de hand liggende maatregel het opleggen van een norm. Overtreding van de norm levert een sanctic op. Opsporing en handharing door bevoegde autoriteiten doen de rest. Het instrument dat de overheid daartoc ten dienste staat is in principe wet- of regelgeving.

\section{Problemen hii codificering van MiO}

Maatschappelijk verantwoord gedrag is cehter niet eenvoudig in een norm te vangen. Ten eerste is matschappelijke verantwoordelijkheid niet eenvoudig te definiëren en is het derhalve moeilijk in wetsteksten om te zetten. Ten tweede suggereert de term malschappelijke verantwoordelijkheid een zekere vrijwilligheid. Het gaat in principe om gedrag dat moreel verplichtend is, mar wettelijk niet. Als maatschappelijke verantwoordelijkheid al in welten te vangen zou zijn, dan zou het ver- 
plichtende karakter van een wet afdoen aan het element van vrijwilligheid. Een derde moeilijkheid is dat maatschappclijk verantwoord ondernemen geen statisch gegeven is, maar eerder een dialoog binnen ondernemingen en tussen maatschappelijke groeperingen en ondernemingen waarbinnen zich voortdurend nicuwe denkbeelden ontwikkelen. Bovendien beperkt iedere norm die de overheid zou opleggen het begrip duurzaam ondernemen, iedere norm wordt een minimumnorm. Het traditionele welgevingsinstrument voldoet niet in dit verband.

\section{Nieune instrumenten}

Het traditionele beleidsinstrumentarium van de overheid biedt onvoldoende mogelijkheden om maatschappelijk verantwoord ondernemen te stimuleren.

De moderne overheid is echter niet voor één gat te vangen. Ministeries hebben cen aantal zeer creatieve beleidsinstrumenten ontwikkeld. Een voorbeeld dat goed aansluit bij het hier besproken onderwerp is het EZ-instrumentarium waarmee het departement hoopt innovatie en ondernemerschap bij het bedrijfsleven te stimuleren ${ }^{3}$.

Innovatief vermogen en ondernemerschap zijn net als duurzaam ondernemen, moeilijk grijpbare begrippen. Toch schroomt de overheid niet deze begrippen, met behulp van innovatieve anbestedingsmethodes en twinning-centra tot onderwerp van beleid te maken. Waarom deze ambtelijke creativiteit niet toegepast op maatschappelijk verantwoord ondernemen?

Een ander voorbeeld van een relatief nieuw beleidsinstrument is de verslaglegging. Verslaglegging geeft geen directe verplichting tot het naleven van een bepaalde norm, maar beoogt op cen indirecte manier goed gedrag af te dwingen. Het stellen van een repressieve norm doet in de meeste gevallen de discussie over een onderwerp verstommen. De regering en Kamer hebben de knoop doorgehakt, de norm is als volgt en u burgers en bedrijfsleven heeft zich daaraan te houden. De verplichting tot verslaglegging is een vorm van regelgeving die in de rechtswetenschap wel omschreven wordt met de term communicatieve of interactieve wetgeving ${ }^{4}$. Communicatieve wetgeving stelt geen directe norm, maar daagt de belanghebbenden uit tot normontwikkeling. De wetgever laat in deze vorm van regelgeving de normvinding over aan het veld. Een voorbeeld van deze vorm van wetgeving is de wetgeving inzake euthanasie. De welgever heeft geen regels over euthanasie gesteld, maar heeft de normvinding over euthanasie overgelaten aan een toetsingscommissie samengesteld uit verschillende deskundigen.
Een ander voorbeeld is het milieujaarverslag. In de memorie van toelichting bij de wijziging van de wet milieubeheer waarbij het milieujaarverslag werd ingevoerd, wordt bewust gekozen voor een open benadering. De doelstelling van de wet is het bedrijfsleven aan te moedigen actief te werken aan adequate bedrijfsinterne milieuzorgsystemen. De memorie van toelichting ${ }^{5}$ :

In het algemeen kan worden gesteld dat het wetsvoorstel past in de tendens naar meer zelfregulering in de samenleving waarbij de verschillende actoren ruimte krijgen om zelf hun gedrag te bepalen en tegelijkertijd elkaar voor dat gedrag ter verantwoording te kunnen roepen.

\section{En verderop:}

"De verplichting om extern verantwoording af te leggen versterkt de noodzaak om in de bedrijfsvocring voorzieningen te treffen om inzicht te krijgen in de milicubelasting van de verschillende bedrijfsactiviteiten.... Anderzijds wordt met dit wetsvoorstel de verantwoordingsplicht geëxpliciteerd, die bedrijven jegens overheid en publiek hebben in de situatic waarin aan hen meer ruimte voor een eigen invulling van de zorg voor het milieu geboden wordt. Het wetsvoorstel heeft mede tot doel om duidelijkheid te scheppen over de wijze waarop bedrijven verantwoording dienen af te leggen door rapportage aan de overheid en het informeren van het publiek".

De wet op het milieujarverslag is vorig jaar in werking getreden. In 1999 werden de eerste proefverslagen gepresenteerd. Uit onderzoek is gebleken dat het resultaat over dit jaar enerzijds wat teleurstellend was. De verslagen voldeden voor een groot deel niet aan eisen van nauwkeurigheid en controleerbaarheid. Anderzijds hebben meer bedrijven een milieujaarverslag opgesteld dan de wettelijk verplichte groep bedrijven die door de minister van Verkeer en Waterstaat waren aangewezen. Het feit dat de verslagen in het eerste verslagjaar niet perfect ziin, wil niet zeggen dat de wetgeving gefaald heeft. Dit is het begin van een proces.

Maatschappelijk verantwoord ondernemen wordt vaak omschreven als een dialoog tussen het bedrijfsleven en maatschappelijke organisaties. De PvdA en GroenLinks zijn van mening dat transparantie een belangrijke rol kan vervullen op twee fronten. Enerzijds kan de overheid ervoor zorgen dat consumenten over betrouwbare informatie over bedrijven en hun producten kunnen beschikken. Anderzijds is transparantie een vereiste voor de dialoog tussen maatschappelijke organisaties en de bedrijven. 


\section{Initiatiefwetsvoorstel}

De keuze voor het opleggen van een verplichting tot verslaglegging was daarmee een feit. Wij beogen met dit wetsvoorstel het einddoel te bereiken door een proces in werking te stellen, waarbij bedrijven in overleg treden met de samenleving en zich daarmee letterlijk verantwoorden.

Verslaglegging over de doelstellingen van ondernemingen op het gebied van duurzaam ondernemen, kan zowel het uitgangspunt van een dialoog zijn, als een bron van informatie voor de consument om zijn of haar koopgedrag aan te passen. In het begin zal het maatschappelijk verslag waarschijnlijk niet veel inzicht geven in de duurzaamheid van de activiteiten van de onderneming. Als het maatschappelijk verslag een rol moet gaan spelen bij het aankoopgedrag van constimenten, moet de informatie die verstrekt wordt op juistheid getoetst kunnen worden. Uiteindelijk is het onze bedoeling om betrouwbare en controleerbare informatie beschikbaar te maken voor consumenten, maar ook voor het bedrijfsleven zelf. Om de kwaliteit van de verslagen te waarborgen zal een vorm van verificatie of social audit in de toekomst wellicht verplicht gesteld moeten worden. In gesprekken met deskundigen op het terrein van sociale verslaglegging, werd echter duidelijk dat het voor een verplichte verificatie op dit moment te vroeg is.

Het belang van een betrouwbare verificatiemethode voor duurzaamheid of maatschappelijk verantwoord ondernemen is groot. Om met de staatssecretaris te spreken, de overheid heeft de taak de transparantie van de markt te bevorderen, met name ten behoeve van de consument.

Verificatie is bovendien een conditio sine qua non voor welk overheidsbeleid op het gebied van sustainable development dan ook.

\section{Definitieve vorm}

GroenLinks en de Partij van de Arbeid zullen geheel in de aard en strekking van het onderwerp maatschappelijk verantwoord ondernemen niet zonder dialoog met de belanghebbende met definitieve voorstellen komen. Wij hebben een uitgebreid discussiestuk voorbereid met een aantal uitgewerkte varianten en zullen dat presenteren aan maatschappelijke organisaties en bedrijfsleven.

Een moderne en sterke overheid legt niet op autoritaire wijze regels op als dat niet nodig is, maar stimuleert wel die processen in de samenleving die zij waardeert. Maatschappelijk verantwoord ondernemen is een onderwerp waar de overheid veel belang bij heeft en waar zij een rol in kan spelen. Niet als ouderwetse regelgever, maar als facilitator die een platform creëert waarop de dialoog tussen bedrijven en stakeholders plaats kan vinden.

NOTEN

1 Begroting van het Ministerie van Economische Zaken voor het 1999, kamerstuk nr 26800 XIII

2 Verslag van het Algemeen overleg met de staatssecretaris van Economische Zaken, kamerstuk nr 26485 nr 2

3 Beleidsnota Economische Zaken, kamerstuk nr 25518

4 Dr. Mr. W. van der Burg, Wetgeving inzake morele kwesties: een procesgerichte benadering, in Ars Aequi 47 (1998) 2 februari

5 Wijziging op de wet Milieubeheer (milieuverslaglegging) Kamerstuk nr 24572, nr. 1-2 